\title{
Analysis the Impact of Strategic Management on the Firm Performance of SMEs in Malaysia
}

\author{
Marieah Binti Omar ${ }^{1}$, Samsudin Wahab ${ }^{2}$, Siti Nur Fadzilah Muhsain ${ }^{3}$, Adi Izhar Che Ami, \\ Nor Aziyah Bakhari ${ }^{4}$ \\ \{marieah186@uitm.edu.my¹, samsudinw@uitm.edu.my², sitinurfadzilah077@uitm.edu.my³, \\ adiizhar@uitm.edu.my${ }^{4}$,noraziyah140@uitm.edu.my ${ }^{5}$ \} \\ Universiti Teknologi MARA Cawangan Pulau Pinang, Malaysia ${ }^{1}$, Universiti Teknologi MARA \\ Cawangan Pulau Pinang, Malaysia ${ }^{2}$, Universiti Teknologi MARA Cawangan Pulau Pinang, Malaysia ${ }^{3}$, \\ Universiti Teknologi MARA Cawangan Pulau Pinang, Malaysia ${ }^{4}$
}

\begin{abstract}
The previous study concluded that most SMEs have paid less attention to their strategic planning processes. In this regard, this study tends to examine theoretically how Malaysian SME companies can use strategic management to effectively formulate growth and development plans. Thus, the goal of this study is to close the research gap by presenting empirical data on strategic management impacts and will explore the extent to which the adoption of strategic management practices like business strategy, organizational structure, competitive advantage, innovation and networking with suppliers among SMEs in Malaysia has increased their number of customers and consequently their business performances
\end{abstract}

Keywords: strategic management, business strategy, organizational structure. Competitive advantage, Innovation, SME, .

\section{Introduction}

Small Medium Enterprise (SME) has always been one of the major contributors in Malaysian economy. As per the SME Annual Report 18/19, SME represent $98.5 \%$ of the business population in Malaysia and contributes $38.3 \%$ to overall country GDP. The report also stated that SME has take up $66.2 \%$ from the overall employment in Malaysia. According to SME Corp official website, the SME is defined by two type of criteria which are turnover and number of full-time employees. Though SMEs lack of resources, many researcher stated that most of these SMEs struggle due to their poor management, lack of management experience and lack of effort due to a lack of strategic planning [1][2]. As SME is different from a large corporation, a different approach to in managing the performance is required. An organization especially SMEs must have an effective tool to monitor firm's performance that can ensure the firm is less dependent on government entity, such as SME Corporation. Developed countries has long been actively conducting research in the area of strategy that SME can take in order to gain superior performance [3]. This study will mainly focus on the strategic management practices in SMEs and how such practices impact their overall performance. 


\section{Methods}

However, there is a little of research into the effect of strategic management practices on SMEs in Malaysia [4][5]. The previous study concluded that most SMEs have paid less attention to their strategic planning processes. In this regard, this study tends to examine empirically how Malaysian SME companies can use strategic management to effectively formulate growth and development plans. Thus, the goal of this study is to close the research gap by presenting theoretical analysis on strategic management impacts and will explore the extent to which the adoption of strategic management practices like business strategy, organizational structure, competitive advantage, innovation and networking with suppliers among SMEs in Malaysia has increased their number of customers and consequently their business performances

\section{Result and Discussion}

\subsection{Contribute to SMEs performance}

\subsubsection{Business Strategy}

Business strategy is the means by which a business sets out to achieve its desired aims (objectives). It could simply be described as long-term business planning. Typically, the business strategy will cover a period of about 3-5 years (sometimes longer). Business strategy may be defined as a set of strategic statements. It summarizes how the company will achieve its objectives, meet the expectations of its customers and maintain a competitive advantage in the marketplace. Business strategy sets priorities for the company and management team and helps to attract and retain the talented employees needed by SMEs.

Small and medium-sized enterprises play an important role in our economic stability and the pillars for industrial development in Malaysia. [6]. Yet the risk of SMEs being wiped out if they are not successful in the current and rapidly evolving market climate is high. To success in competition, strategic planning implementation must rely to the time and resources effectively. Most of the failure come from their planning failure which is did not matching their resources. A study from [7] suggest that an organization lacks a clearly established plan and does not have a viable basis for establishing and retaining a competitive edge in the marketplace. Several studies indicate a positive relationship between strategic planning and market success [8][9][10][11]. Researcher in [9] claim that structured strategic planning is a hypothetical practice meant exclusively for larger companies and thus has little impact on financial performance.

Study from [12] found that business strategy has a significant connection with organizational performance. The study showed clearly that SME owners need a business strategy to improve and enhance corporate efficiency that can contribute to business continuity. Effective strategies must meet both government and environmental wide business objectives [13]. Business strategy suitable for small- to medium-sized company managers / owner-managers [14]. Thus, the hypotheses have been proposed to investigate the relationship between business strategy and firm performance of SMEs.

\subsubsection{Organizational Structure}

The organizational structure of strategic management refers to a sustainable organization within a business to carry out the tasks set out in its strategy. These include the distribution of authority and responsibility, the relationship of reporting and the mechanism for integrating its functions [15] describe structure as: 
"A formal system of task and reporting relationships that controls, co-ordinates and motivates employees so that they work together to achieve Organizational goals"

Some strategies and environments require decentralized structures, while others require centralized structures. Alfred Chandler stressed the importance of taking a long-term view of the future. In his 1962 ground-breaking work Strategy and Structure, Chandler showed that a long-term coordinated strategy was needed to give the company structure, direction and focus. He says it is concise, the structure follows the strategy. The corporation and its staff are responsible for the best organizational structure. The structure framework has a direct influence on the organizational strategy of the company. The best organizational structure of the company affects the behavior of an organization. The structure not only forms the organizational skills but also the performance processes. The idea that the organizational structure shapes performance was endorsed by [16]. Structure's effect on supply chain management through performance mediation was studied and it found a positive impact on performance in a stable setting of the formal structure [17]. In addition, the project management team can benefit from a suitable organizational structure to achieve high project performance through productivity and quality gains [18]. Researcher in [19] also found that the project management team will benefit from a suitable organizational structure to achieve high project performance through efficiencies and productivity gains.

Most organizations are influenced by a specific and predictable organizational structure [20]. Resercher from [21] revealed in order to achieve the set goals, it should aim for a welldefined structure in place because organizational structure has an impact on firm performance. Small businesses looking for a useful organizational framework must understand that the mechanism can be complicated because it is mostly left to a start-up organization [22]. Thus, the hypotheses have been proposed to investigate the relationship between organizational structure and firm performance of SMEs.

\subsubsection{Competitive Advantage}

A competitive advantage is what makes products or services of a business better than any other choices made by a customer. The competitive advantage may be the most commonly used concept in strategic management, but it is still poorly defined and operational. Researcher in [23] describe competitive advantage as superiority gained by a company when it can give equal value but more advantages than its rivals. The study also identified two basic forms of competitive advantage: cost advantage and differentiation. The researcher also believes that a competitive advantage helps the business to generate higher prices and greater results for its customers. From [24] stated that "An enterprise has a Competitive Advantage if it is able to create more economic value than the marginal (breakeven) competitor in its product market".

Firm's achieved competitive advantage with good strategic management [25]. Small businesses who understand their customers can have a competitive advantage, which means that they can benefit from higher pricing and consumer loyalty. Greater utilization of capacity will then lead to cost reduction [26]. Much similar has been noticed on the process of the strategic management of independent film companies and all the various strategic management measures have affected the competitive advantage of the companies [27]. The competitive advantage and corporate strategies of SMEs led significantly to their respective rise in customer numbers and market shares [28]. In order to achieve a competitive advantage which not only matches their competitors' averages but also exceeds the averages of industry performing, organizations first need to understand the connection between their business strengths and weaknesses and the potential effect on their firm's competitive advantage and performance. 
Competitive advantage and firm performance are two distinct buildings with a seemingly complicated relation [29]. Competitive advantages should be streamlined with respect to costs leadership, product and service diversification, and sensitivity to the needs of a particular customer community to be compatible with both internal and external company opportunities and obstacles [30]. Thus, the hypotheses have been proposed to investigate the relationship between competitive advantage and firm performance of SMEs.

\subsubsection{Innovation}

The definitions of innovation may vary from one context to another. Key function of innovation is basically change. The concept of innovation has always been complex, and ambiguity has been generated over the last decade as political, social and technical aspects of life have changed rapidly. In [31] highlighted that innovation measures such as R\&D and patent number do not apply to all firms, and therefore may not be enough innovation measures. There are common characteristics in these definition despites of various meanings of innovation. Innovation can be describe as a technology implementation that enhances and gives users added value [32].

Innovation is an integral part of the survival and development of SMEs [33]. Innovation has a strong impact on firm performance [34]. In [35] stresses that although innovation is not enough to ensure the survival and success of SMEs, innovation is important for SME's success. Many researcher categorized innovation in four category; product innovation, process innovation, marketing innovation and organizational innovation [36] [37] [38]. This study will adopt product innovation and marketing innovation measures as instruments for measuring innovation in the firm.

In [39] indicates that by implementing product innovation practices with a strong emphasis on launching new products, firm will boost their performance. According to [40], "A product innovation is the introduction of a good or service that is new or significantly improved with respect to its characteristics or intended uses". Other functional aspect also improving such as technical specifications, components and materials, incorporated software, user friendliness. Marketing innovation are a new method of marketing that change the design or packaging of the product, placement, promotion and pricing [40]. Marketing innovation may open new markets, address customer needs, reposition products in the market to increase sales. Some researchers highlight that marketing innovation is one of the crucial factors of innovation for SMEs. Therefore, innovation is one of strategic management tools to support SMEs performance. Thus, the hypotheses have been proposed to investigate the relationship between innovation and firm performance of SMEs.

\subsubsection{Business Network}

Business networks are defined as close and lasting ties to key suppliers and customers of a company [41], which generally consist of existing linkages between different companies [42]. At the fundamental level, a business requires suppliers to provide resources for the goods or services they offer, or to provide resources to operate the business. Frequent connections and close ties with suppliers could have a beneficial impact on information and knowledge exchange and flow and could thus enhance processes and performance [43]. The supplier management method helps to quantify the time, resources and energy used to create good ties with suppliers. Organizations who use their clients and suppliers as resources during childbirth are more likely to grow more quickly [44]. This study will measure the relationship with suppliers as instruments in the business network. 
An outstanding buyer-seller relationship is a long-term win-win collaboration. A responsive supplier is an advantage for the entire business. A supplier who is handled in a friendly way, integrity and fairness can provide a quality product at the best price, offer good service and respond to special needs and emergencies. [45] opines that entrepreneurs will be able to get quality products, guarantee good service and ensure prompt delivery by forming relationships with suppliers. Suppliers influence the company dramatically on the expense, quality and distribution of goods and services. Enterprises need to build supplier strategies to enhance procurement capabilities for suppliers and to promote collaborations with suppliers so that market performance is increased [46]. In view of the short product life cycles, intense global competition, the need for sustainability and the increasingly growing consumer demands, cooperation between companies and their suppliers is becoming more and more relevant [47].

In Malaysia, some SME entrepreneurs use a strategic market network to manage their suppliers and learn about their competitors' strengths and weaknesses [48]. Furthermore, the researcher also found that strategic business network has significantly and positively affect business performance. New firms, particularly in the searching for new information, are more reliable in business network compared to those established. Thus, the hypotheses have been proposed to investigate the relationship between business network and firm performance of SMEs.

\section{Conclusion}

The Figure 1 below is a proposed conceptual framework for explaining the relationship between strategic management practices and their impact towards firm performance of SMEs. The framework assumes the resultant impacts of strategic management practices such as business strategy, organizational structure, competitive advantage, innovation and business network directly impact the performance of SMEs in term of non-financial aspects.

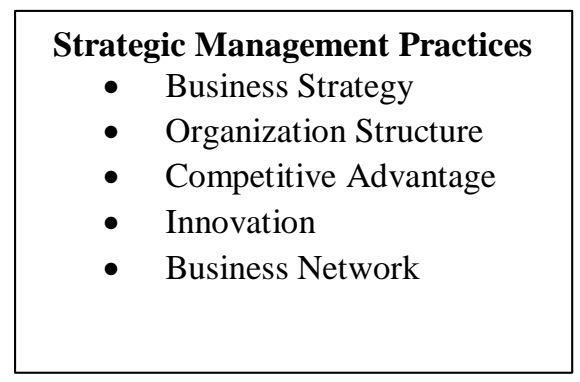

Independent Variables (IV)

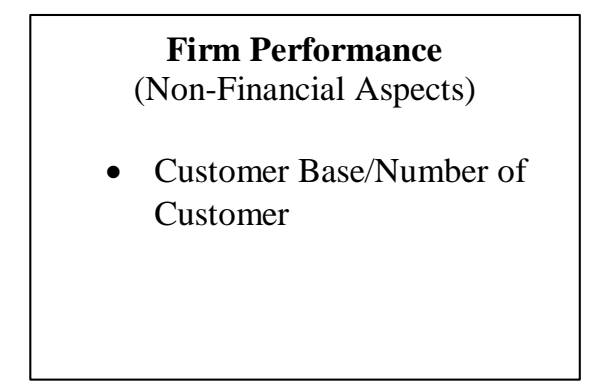

Dependent Variables (DV)

Figure 1: Conceptual Framework showing the relationship between Strategic Management Practices and Firm Performance

Acknowledgements. Special appreciation to Universiti Teknologi MARA, Cawangan Pulau Pinang for providing the budget for this research proposal. 


\section{References}

[1] F. Nwankwo, N. Ewuim, and N. Asoya, "Role of Cooperatives in Small and Medium Scale Enterprises (SMEs) Development in Nigeria: Challenges and the Way Forward," African Res. Rev., 2012, doi: 10.4314/afrrev.v6i4.10.

[2] Y. Kraja and D. Osmani, "Competitive Advantage and Its Impact in Small and Medium Enterprises (SMEs) (Case of Albania)," Eur. Sci. J., 2013.

[3] W. M. N. bin W. M. Nasir, A. Al Mamun, and J. Breen, "Strategic Orientation and Performance of SMEs in Malaysia," SAGE Open, 2017, doi: 10.1177/2158244017712768.

[4] M. K. Moorthy et al., "A Study on Factors Affecting the Performance of SMEs in Malaysia," Int. J. Acad. Res. Bus. Soc. Sci., 2012, doi: ISSN: 2222 - 6990.

[5] K. Mohamad Radzi, M. N. Mohd Nor, and S. Mohezar Ali, "The impact of internal factors on small business success: A case of small enterprises under the felda scheme," Asian Acad. Manag. J., 2017, doi: 10.21315/aamj2017.22.1.2.

[6] A. S. Saleh, P. Caputi, and C. Harvie, "Perceptions of business challenges facing Malaysian SMEs : some preliminary results," Res. Online, 2008.

[7] N. M. Scarborough and T. W. Zimmerer, "Effective Small Business Management," Facilities, 2011.

[8] J. S. Bracker, B. W. Keats, and J. N. Pearson, "Planning and financial performance among small firms in a growth industry,” Strateg. Manag. J., 1988, doi: 10.1002/smj.4250090606.

[9] R. . Pierce, J.A. dan Robinson, Strategic management, Formulation Implementation and Control. Malaysia: McGraw Hill. 2000.

[10] W. E. Hopkins and S. A. Hopkins, "Strategic planning-financial performance relationships in banks: A causal examination," Strateg. Manag. J., 1997, doi: 10.1002/(sici)10970266(199709)18:8<635::aid-smj904>3.0.co;2-\%23.

[11] M. Anderson and A. S. Sohal, "A study of the relationship between quality management practices and performance in small businesses," Int. J. Qual. Reliab. Manag., 1999, doi: $10.1108 / 02656719910289168$.

[12] C. Sriviboon, "Strategy and performance interrelation: The mediating role of the solidarity," $J$. Secur. Sustain. Issues, 2020, doi: 10.9770/JSSI.2020.9.M(19).

[13] O. Sunday and E. E. Joseph, "Inventory Management and SMEs Profitability. A Study of Furniture Manufacturing, Wholesale and Eatery Industry in Delta State, Nigeria," J. Financ. Account., 2017, doi: 10.12691/jfa-5-3-1.

[14] A. J. Abosede, K. A. Obasan, and O. J. Alese, "Strategic Management and Small and Medium Enterprises (SMEs) Development: A Review of Literature," Int. Rev. Manag. Bus. Res., 2016.

[15] A. Buchanan, D., Huczynski, Organizational Behaviour. An Introductory Text, 5th ed. Prentice Hall, 2004

[16] J. Clemmer, "The Leader's Digest: Timeless Principles for Team and Organization Success," TCG Press, 2013.

[17] R. Germain, C. Claycomb, and C. Dröge, "Supply chain variability, organizational structure, and performance: The moderating effect of demand unpredictability," J. Oper. Manag., 2008, doi: 10.1016/j.jom.2007.10.002.

[18] W. Arthur, T. B. Kyte, A. J. Villado, C. A. Morgan, and S. S. Roop, "Introducing a subject matter expert-based utility analysis approach to assessing the utility of organizational interventions such as crew resource management training," Int. J. Aviat. Psychol., 2011, doi: 10.1080/10508414.2011.556504.

[19] M. A. Zaki, H. S. Hussien, H. M. Sanad, and S. S. El-Khoriby, "Analyzing Organizational Structure for Contracting Firms' of Classification 'a', Egypt,” J. Eng. Sci. Assiut Univ. Fac. Eng., 2015.

[20] F. A. Csaszar, "Organizational structure as a determinant of performance: Evidence from mutual funds," Strategic Management Journal. 2012, doi: 10.1002/smj.1969.

[21] M. A. Ajagbe, S. Maduenyi, A. O. Oke, and F. Olatunji, "Impact of Organisational Structure on Organisational Performance," Int. Conf. African Dev. Issues, 2015. 
[22] "Organizational Structure," Inc.

[23] M. E. Porter, "From Competitive Advantage to Corporate Strategy," in Readings in Strategic Management, 1989.

[24] J. B. Barney and W. S. Hesterly, Strategic management and competitive advantage. Pearson Education Upper Saddle River, NJ, 2009.

[25] O. A. Otungu, W. J. Nyongesa, O. E. ochieng, and K. simeon, "STRATEGIC MANAGEMENT: THE LINK BETWEEN THE AGENCY THEORY AND THElrCOMPANY'S COMPETITIVE ADVANTAGE,”Int. J. Bus. Soc. Sci., 2011.

[26] E. Papulova and Z. Papulova, "Competitive strategy and competitive advantages of small and medium manufacturing enterprises in SLOVAKIA," Geogr. Ann. Ser. B Hum. Geogr., 2015, doi: $10.1002 /$ sej.

[27] I. Vitkauskaite, "Strategic management of independent film production companies," 2017.

[28] M. E. Agwu, "Analysis of the impact of strategic management on the business performance of SMEs in Nigeria," Acad. Strateg. Manag. J., 2018.

[29] H. Ma, "Competitive advantage and firm performance," Compet. Rev., 2000, doi: 10.1108/eb046396.

[30] P. Potjanajaruwit, "Competitive advantage effects on firm performance: a case study of startups in Thailand," J. Int. Stud., 2018, doi: 10.14254/2071-8330.2018/11-3/9.

[31] Ø. Moen, T. Tvedten, and A. Wold, "Exploring the relationship between competition and innovation in Norwegian SMEs," Cogent Bus. Manag., 2018, doi: 10.1080/23311975.2018.1564167.

[32] M. I. Haddad, I. A. Williams, M. S. Hammoud, and R. J. Dwyer, "Strategies for implementing innovation in small and medium-sized enterprises," World J. Entrep. Manag. Sustain. Dev., 2019, doi: 10.1108/WJEMSD-05-2019-0032.

[33] J. Yadollahi Farsi and M. Toghraee, "Identification the main challenges of small and medium sized enterprises in exploiting of innovative opportunities (Case study: Iran SMEs)," J. Glob. Entrep. Res., 2014, doi: 10.1186/2251-7316-2-4.

[34] I. Hajar, "The Effect of Business Strategy on Innovation and Firm Performance in the Small Industrial Sector," Int. J. Eng. Sci., 2015.

[35] A. P. Ndesaulwa and J. Kikula, "The Impact of Innovation on Performance of Small and Medium Enterprises ( SMEs ) in Tanzania: A Review of Empirical Evidence," J. Bus. Manag. Sci., 2016, doi: 10.12691/jbms-4-1-1.

[36] M. U. Hassan, S. Shaukat, M. S. Nawaz, and S. Naz, "Effects of Innovation Types on Firm Performance: an Empirical Study on Pakistan's Manufacturing Sector," Pakistan J. Commer. Soc. Sci., 2013.

[37] M. M. Rosli and S. Sidek, "The Impact of Innovation on the Performance of Small and Medium Manufacturing Enterprises: Evidence from Malaysia," J. Innov. Manag. Small Mediu. Enterp., 2013, doi: 10.5171/2013.885666.

[38] D. C. Roach, J. A. Ryman, and J. Makani, "Effectuation, innovation and performance in SMEs: an empirical study," Eur. J. Innov. Manag., 2016, doi: 10.1108/EJIM-12-2014-0119.

[39] A. Osei, S. Yunfei, W. Appienti, and S. Forkuoh, "Product Innovation and SMEs Performance in the Manufacturing Sector of Ghana," Br. J. Econ. Manag. Trade, 2016, doi: 10.9734/bjemt/2016/29906.

[40] OECD/Eurostat, Oslo Manual: Guidelines for Collecting and Interpreting Innovation Data, 3rd Edition, The Measurement of Scientific and Technological Activities. 2005.

[41] J. Johanson and J. E. Vahlne, "The Uppsala internationalization process model revisited: From liability of foreignness to liability of outsidership," J. Int. Bus. Stud., 2009, doi: 10.1057/jibs.2009.24.

[42] J. C. Anderson, H. Hakansson, and J. Johanson, "Dyadic Business Relationships within a Business Network Context," J. Mark., 1994, doi: 10.2307/1251912.

[43] M. Roushdy, M. Mohamed, S. Hesham, S. Elzarka, and L. Hafez, "Investigating the Impact of Suppliers Relationship Management on Firms' Performance: A Multiple Case Study Approach on Manufacturing Companies in Egypt," Int. Conf. Oper. Excell. Serv. Eng., 2015. 
[44] J. L. Capelleras and F. J. Greene, "The determinants and growth implications of venture creation speed," Entrep. Reg. Dev., 2008, doi: 10.1080/08985620701855683.

[45] B. N. Neneh, "Customer orientation and SME performance: the role of networking ties," African J. Econ. Manag. Stud., 2018, doi: 10.1108/AJEMS-03-2017-0043.

[46] Y. Xu and Q. Peng, "An Empirical Study on the Relationship between Green Supplier Development and Firm Performance," Am. J. Ind. Bus. Manag., 2018, doi: 10.4236/ajibm.2018.84064.

[47] K. Amoako-Gyampah, K. G. Boakye, E. Adaku, and S. Famiyeh, "Supplier relationship management and firm performance in developing economies: A moderated mediation analysis of flexibility capability and ownership structure," Int. J. Prod. Econ., 2019, doi: 10.1016/j.ijpe.2018.11.021.

[48] E. F. Surin, O. T. Edward, M. H. F. Hussin, and I. Ab. Wahab, "Recognising the Importance of Strategic Business Network on Business Performance of Sme Manufacturing Firms in Malaysia: Analysing the Moderating Influence of Human Capital and Business Environment," Int. J. Arts Sci., 2017. 